\title{
Budaya Menonton Televisi di Indonesia: Dari Terrestrial Hingga Digital
}

\author{
Rangga Saptya Mohamad Permana ${ }^{1}$, Aceng Abdullah², dan Jimi Narotama Mahameruaji ${ }^{3}$ \\ 1,2,3Program Studi Televisi dan Film, Fakultas Ilmu Komunikasi, \\ Universitas Padjadjaran, Bandung
}

\begin{abstract}
ABSTRAK
Sejak TVRI mulai mengudara pada tahun 1962, televisi menjadi salah satu media hiburan dan informasi yang tidak dapat dilepaskan dari keseharian orang Indonesia. Kegiatan menonton televisi tersebut menciptakan budaya menonton televisi di kalangan audiens televisi Indonesia. Budaya menonton televisi di era televisi terrestrial dan era televisi digital memiliki perbedaan yang signifikan dan menarik untuk digali lebih lanjut. Tujuan dari kajian ini adalah untuk mengetahui budaya menonton televisi di Indonesia, dari mulai menggunakan media televisi terrestrial hingga media televisi digital. Metode penelitian deskriptif-kualitatif digunakan dalam kajian ini dengan metode pengumpulan data menggunakan metode telaah dokumen. Hasil kajian menunjukkan bahwa budaya menonton televisi terrestrial yang bersifat analog dan mengandalkan antena di Indonesia adalah kegiatan yang bersifat komunal dan kolektif, sekaligus menjadi ajang bertukar cerita keseharian para audiens. Sedangkan budaya menonton televisi digital yang mengandalkan jaringan Internet di Indonesia merupakan kegiatan yang personal dan individual, di mana audiens dapat memilih tontonan sesuai minat dan budget mereka. Penggunaan smartphone membuat kegiatan menonton televisi dapat dilakukan kapan pun dan di manapun, dengan syarat tersedia jaringan internet yang memadai.
\end{abstract}

Kata-kata Kunci: Budaya; digital; Indonesia; televisi; terrestrial

\section{Culture of Watching Television in Indonesia: From Terrestrial To Digital}

\begin{abstract}
Since TVRI began broadcasting in 1962, television has become one of the entertainment and information media that cannot be separated from the daily lives of Indonesians. The television-watching activity created a culture of watching television among Indonesian television audiences. The culture of watching television in the era of terrestrial television and the era of digital television has a significant difference and interesting to be explored further. The purpose of this study was to find out the culture of watching television in Indonesia, from starting to use terrestrial television media to digital television media. Descriptive-qualitative research methods are used in this study with data collection methods using the document review method. The results of the study indicate that the culture of watching terrestrial television that is analogous and relies on antennas in Indonesia is a communal and collective activity, as well as a place to everyday stories exchange of audiences. While the culture of watching digital television that relies on internet networks in Indonesia is a personal and individual activity, where the audience can choose to watch according to their interests and budget. The use of smartphones makes watching television activities can be done anytime and anywhere, with the condition that an adequate internet network is available.
\end{abstract}

Keywords: Culture; digital; Indonesia; television; terrestrial

Korespondensi: Rangga Saptya Mohamad Permana. Universitas Padjadjaran, Jl. Raya Bandung Sumedang km 21. Kode Pos 45365. Email: rangga.saptya@unpad.ac.id 


\section{PENDAHULUAN}

Dalam tataran formal, definisi budaya adalah tatanan pengetahuan, pengalaman, kepercayaan, nilai, sikap, makna, hirarki, agama, waktu, peranan, hubungan ruang, konsep alam semesta, objek-objek materi dan milik yang diperoleh sekelompok besar orang dari generasi ke generasi melalui usaha individu dan kelompok (Porter \& Samovar, 2006). Lonner dan Malpass mengungkapkan bahwa budaya merupakan yang dibuat manusia dalam lingkungan (Samovar, Porter, \& McDaniel, 2014).

Budaya dapat disebarluaskan melalui media, termasuk televisi. Di Indonesia, televisi pertama kali diperkenalkan pada tahun 1962, ketika Indonesiamendapatkankehormatanuntuk menyelenggarakan pesta olahraga Asian Games di Jakarta. Sejak saat itu, televisi seolah tidak dapat dilepaskan dari keseharian masyarakat Indonesia. Dahulu, TVRI adalah satu-satunya saluran televisi resmi pemerintah di Indonesia, namun sejak dipublikasikannya aturan baru dalam bidang penyiaran dan media massa sebagai hasil reformasi yang dicanangkan sejak tahun 1997, jumlah stasiun televisi di Indonesia tumbuh pesat, ditambah lagi munculnya televisi kabel dan berbayar dengan pilihan program yang beragam (Cangara, 2007).

Bila dipandang dari perspektif sosial- budaya, semakin banyaknya pilihan audiens untuk menonton acara-acara yang mereka sukai menunjukkan bahwa industri budaya menghasilkan konten yang terstandardisasi. Selain itu, industri budaya juga menghasilkan "audiens itu sendiri dengan cara lingkaran manipulasi dan retroaktif yang diperlukan di mana kesatuan sistem (produksi dan konsumsi pemaknaan) tumbuh lebih kuat". Hal ini menekankan pada fakta bahwa penyiaran menghasilkan konten untuk khalayak pada saat yang sama ketika ia memproduksi khalayak untuk konten itu. Dengan kata lain, massa dibentuk oleh broadcast (Holmes, 2012).

Pada tahun 2018, setidaknya terdapat 16 televisi swasta nasional di Indonesia. Keenambelas televisi swasta nasional tersebut adalah RCTI, SCTV, MNCTV, ANTV, Indosiar, Global TV, Trans TV, Trans 7, tvOne, Metro TV, iNews TV, RTV, Kompas TV, O-Channel, SpaceToon dan NET. TV. Semuanya bersaing dengan program-program yang diproduksinya, yang berdampak pada rating dan share program-program televisi tersebut. Semakin tinggi rating dan share sebuah program televisi, maka kemungkinan iklan dan sponsor yang tayang dalam sebuah program akan meningkat. Dengan banyaknya iklan yang masuk, maka keuntungan yang diraih televisi pun akan meningkat (Permana \& Mahameruaji, 2019).

Menonton televisi merupakan aktivitas 
yang mudah, murah, dan menyenangkan. Pada saat menonton televisi, indra yang berperan utama adalah penglihatan dan pendengaran, pemirsa melihat gambar-gambar yang menarik sambil mendengarkan suara berupa musik maupun kata-kata pengantar mengenai gambargambar yang sedang ditayangkan sehingga acara tersebut dapat dinikmati (Wulan, 1999).

Hingga akhir dekade awal 2000-an, setidaknya ada lima cara penyampaian program televisi yang telah dilakukan, yaitu: overthe-air reception of network and local station program, cable, digital cable, wireless cable, dan Direct Broadcast Satellite (DBS). Setelah Internet muncul, tren streaming pun digunakan dalam siaran televisi (Ardianto, Komala, \& Karlinah, 2007). Azikin mengemukakan bahwa streaming merupakan proses pengiriman data berkesinambungan yang dilakukan secara broadcast melalui Internet untuk ditampilkan oleh aplikasi streaming pada gawai penggunanya. Paket-paket data yang dikirimkan telah dikompresi untuk memudahkan pengirimannya melalui Internet (Fachruddin, 2014). Dengan keberadaan Internet, hadir pula istilah Internetatau media baru. Menurut Chun, Internetmerupakan pernyederhanaan istilah terhadap bentuk media di luar lima media massa konvensional, yaitu televisi, radio, majalah, koran, dan film. Sifat Internet adalah cair (fluids), konektivitas individual dan menjadi sarana untuk membagi peran kontrol dan kebebasan (Cholis \& Wardiana, 2018).

Darma mengungkapkan bahwa streaming akan secara langsung mengoperasikan file video atau audio yang terletak pada server, dan bisa langsung dioperasikan pada gawai pengguna sesaat setelah ada permintaan dari pengguna. Perencanaan pembuatan aplikasi ini memakai komponen Tvideo Graber v7.5 untuk proses capture dan merekam stream audio dan video, sedangkan SUI Pack D7 dipakai guna memperhalus interface media player untuk streaming. Adapun program Delphi 7 dipakai untuk membuat aplikasi yang akan digunakan untuk proses streaming penyiaran televisi (Fachruddin, 2014). Aktivitas dari beragam aplikasi ini menghasilkan siaran televisi yang dapat langsung diakses melalui gawai penggunanya.

Berdasarkan deskripsi di atas, penulis tergerak untuk melakukan sebuah kajian mengenai budaya menonton televisi di Indonesia, mulai dari zaman televisi konvensional/terrestrial mengudara dan hanya menjadi satu-satunya Internet untuk menikmati acara-acara televisi sampai pada pergeseran kebiasaan menonton televisi dengan hadirnya Internet dan media digital di Indonesia. Tujuan dari kajian ini adalah untuk mengetahui budaya menonton televisi di Indonesia, dari mulai menggunakan media televisi terrestrial hingga 
media televisi digital.

\section{TINJAUAN PUSTAKA}

Terkait dengan budaya menonton televisi di Indonesia, Rukman Pala (2017) telah mempublikasikan sebuah hasil riset mengenai televisi dan masyarakat perkotaan. Berdasarkan hasil risetnya, ditemukan bahwa dari aspek aktivitas menonton, terdapat khalayak yang menonton televisi secara konvensional maupun inkonvensional. Begitupun dalam aspek penyiaran, menonton televisi secara streaming telah dilakukan, selain juga aktivitas menonton televisi analog (Pala, 2017).

Mengacu pada penelitian yang telah dilakukan Pala, pada umumnya $(88,6 \%)$ responden masih terbiasa menonton televisi secara konvensional. Sisanya (11,4 \%) mengungkapkan bahwa mereka terbiasa menonton televisi secara inkonvensional. Mayoritas responden menonton televisi secara online menggunakan gawai mereka (smartphone yang terhubung dengan jaringan Internet). Mayoritas responden (45,0\%) melakukannya "hampir setiap hari”. Selanjutnya (37,9\%) mereka melakukannya dengan frekuensi "setiap hari". Mayoritas responden (34,3\%) menggunakan waktu antara $>1$ jam -2 jam. Banyak juga responden yang menonton televisi $>3$ jam - 4 jam (30,7\%) (Pala, 2017).
Dari aspek tempat menonton, mayoritas responden $(92,9 \%)$ menonton televisi di rumah. Terkait dengan jenis media yang digunakan untuk menonton televisi, mayoritas responden $(88,6 \%)$ menggunakan "media televisi konvensional". Realita ini tentu agak mengherankan, mengingat mayoritas responden $(80,0 \%)$ telah mengetahui adanya televisi online yang dapat diakses untuk menonton televisi (Pala, 2017).

Konvergensi media tidak dapat dilepaskan dari perkembangan teknologi televisi di seluruh dunia. Konvergensi media disebabkan oleh percepatan miniaturisasi peralatan canggih dan kemampuan untuk mengompres data menjadi bit digital yang kecil sehingga mudah disimpan dan disalurkan. Perusahaan-perusahaan media, baik yang produknya berbasis teknologi cetak, elektronik, atau fotografis, seluruhnya terlibat dalam konvergensi ini (Vivian, 2015).

Konvergensi media ini juga sekarang telah merambah dunia pertelevisian di Indonesia, di mana televisi siaran mendistribusikan konten-kontennya tidak hanya secara terrestrial saja, tetapi juga melalui jaringan digital. Perkembangan teknologi digital yang berbasiskan komputer dan Internet ini juga turut membidani lahirnya berbagai Internet yang dapat digunakan sebagai media distribusi konten program-program stasiun televisi. Kini, hampir semua stasiun televisi memiliki situs streaming- 
nya sendiri (Permana \& Mahameruaji, 2019).

Munculnya teknologi komputasi mengubah lanskap media dalam berbagai cara penting. Pertama, konten media sekarang dapat dibuat dalam bentuk digital, disimpan dalam kode biner 1 dan 0 . Ini berarti bahwa bentuk-bentuk media yang secara tradisional berbeda - teks, gambar, audio, dan video — sekarang menyatu. Dalam istilah digital, tidak ada perbedaan antara film, lagu yang direkam, foto-foto, dan bab e-book; mereka semua adalah kumpulan informasi digital. Perangkat media juga tidak lagi berbeda. Dahulu, rekaman vinil hanya dapat diputar pada fonograf. Kini, rekaman digital dapat dibuat, disalin, didistribusikan, dan diputar pada perangkat yang terkomputerisasi dengan perangkat lunak yang sesuai: komputer desktop, pemutar MP3, ponsel, dan sejenisnya.

Kedua, digitalisasi juga mengubah dunia produksi media. Penulis mengganti pena dengan pengolah kata. Pembuat film beralih ke teknik merekam dan mengedit video digital. Musisi memanipulasi rekaman dalam program perangkat lunak. Dan, dalam beberapa kasus, pembuatan media untuk berbagai Internet digabungkan. Misalnya, jurnalis sekarang secara rutin membuat konten yang cocok untuk edisi cetak surat kabar mereka serta untuk siaran dan distribusi online; perbedaan antara media yang berbeda menjadi kurang signifikan.

Ketiga, kebangkitan Internet menyediakan
Internet global yang belum pernah terjadi sebelumnya, di mana konten media berbasis digital dapat didistribusikan dan dikonsumsi. Internet memudahkan distribusi konten media, membagikannya, dan menemukan segala macam konten media baru. Sebelumnya, perangkat terpisah - buku, fonograf, pesawat televisi, radio, dan sebagainya - diperlukan untuk mengakses berbagai bentuk media. Sekarang, Internet dengan cepat mengirimkan semua ini ke komputer desktop mana pun dengan akses Internet. Lewat sebuah laman di Internet, khalayak dapat mengakses berbagai bentuk media massa dalam satu waktu. Di saat yang bersamaan, khayalak dapat memperoleh informasi dalam bentuk tulisan, foto, audio, hingga video. Informasi tersebut juga bisa diakses di mana saja dan kapan saja (Widiarini, Karlinah, \& Herawati, 2018).

Keempat, komputer, digitalisasi, dan Internet memungkinkan interaktivitas yang lebih besar di antara pengguna media, dan antara pengguna media dan konten media. Ini memungkinkan pengguna untuk mencari berbagai konten yang lebih luas, menyesuaikan produk media dan opsi pengiriman, memberikan umpan balik, berbagi dan berdiskusi dengan teman-teman, dan bahkan membuat konten media asli, menjadi produsen dan juga konsumen.

Kelima, seiring kemajuan teknologi, 
komputer menjadi lebih kecil dan semakin mobile. Smartphone sebenarnya bukan ponsel dalam arti tradisional sama sekali; itu adalah komputer seluler, yang salah satu fungsinya adalah melakukan panggilan "telepon". Munculnya teknologi seluler telah mencakup komputer tablet yang lebih kecil, smartphone, dan pemutar MP3 portabel bersamaan dengan pasar yang muncul dari perangkat komputasi yang dapat dipakai dalam bentuk kacamata dan jam tangan. Semua perangkat ini membuatnya lebih mudah untuk mengakses konten media, memperluas tempat-tempat di mana kita dapat menggunakan media, dan meningkatkan jumlah waktu yang kita habiskan untuk terhubung ke media dan jaringan komunikasi.

Perubahan teknologi yang tumpang tindih ini memiliki dampak mendalam pada produksi dan konsumsi media dan telah mengubah berbagai industri media. Tetapi penting untuk menegaskan kembali bahwa perubahan teknologi tidak menentukan evolusi media. Sebaliknya, seperti yang akan kita lihat, teknologi hanyalah salah satu dari sejumlah faktor yang saling berinteraksi yang membentuk perkembangan dan penggunaan media.

Munculnya Internet adalah contohnya. Perubahan dalam teknologi komputer adalah kondisi yang dibutuhkan tetapi tidak cukup untuk keberadaan Internet. Butuh pembiayaan dan peraturan pemerintah untuk membantu

mengatur dan meluncurkan sistem Internet, terutama di luar universitas. Internet pada awalnya disusun sebagai jaringan komunikasi terdesentralisasi yang mampu berfungsi setelah serangan nuklir di lokasi-lokasi pusat seperti Washington, DC. Karena itu, banyak dana untuk mengembangkan Internet berasal dari uang pajak publik melalui anggaran Pentagon atas nama pertahanan nasional. Ini adalah contoh nyata dari lembaga sosial eksternal yang secara langsung mempengaruhi perkembangan teknologi. Kemudian, Internet disebut-sebut sebagai jalan raya informasi revolusioner, yang berpotensi berfungsi sebagai sarana untuk mendidik dan melibatkan warga negara dalam masyarakat demokratis. Namun, seiring berjalannya waktu, aplikasi komersial Internet menjadi yang terpenting dengan perusahaan media baru raksasa yang menggunakan teknologi untuk mengiklankan, menjual, dan mengirimkan produk dengan cara baru, dalam beberapa kasus merusak janji demokrasi. Intinya adalah bahwa, sepanjang sejarah media, teknologi dengan sendirinya tidak pernah mengarah secara jelas ke arah yang spesifik; melainkan, kekuatan sosial yang lebih luas telah menyalurkan pengembangan dan penerapan kapabilitas teknologi (Croteau \& Hoynes, 2014). 


\section{METODE PENELITIAN}

Artikel ini memaparkan dan membahas tentang berbagai hal mengenai budaya menonton televisi di Indonesia, mulai dari penggunaan Internet televisi terrestrial hingga televisi digital dengan metode deskriptif-kualitatif. Riset deskriptif cukup memaparkan situasi atau peristiwa. Riset ini tidak mencoba untuk mencari atau menjelaskan sebuah hubungan, bukan berbentuk uji hipotesis atau memprediksi (Rakhmat, 2012). Umumnya, format deskriptifkualitatif dilakukan pada riset berbentuk studi kasus. Format deskriptif-kualitatif studi kasus memfokuskan diri pada sebuah unit tertentu dari sekian banyak realita (Bungin, 2011). Tujuan dari penelitian deskriptif-kualitatif adalah untuk menjelaskan fenomena sedalamdalamnya, dengan cara mengumpulkan data dan menganalisisnya menggunakan metode studi kasus (Candraningrum, 2017). Jadi, dalam artikel ini, penulis berusaha untuk memaparkan dan memusatkan perhatian pada bagaimana budaya menonton televisi di Indonesia dengan menggunakan Internet televisi terrestrial hingga televisi digital, dengan metode pengumpulan data menggunakan metode telaah dokumen.

Berkaitan dengan dokumen, Bogdan berasumsi bahwa mayoritas tradisi penelitian kualitatif menggunakan dokumentasi pribadi secara luas guna merujuk pada narasi orang pertama yang dihasilkan oleh seorang individu yang menggambarkan tindakan, pengalaman, dan keyakinannya sendiri (Sugiyono, 2010). Penulis menggunakan teknik pengumpulan data dengan dokumentasi atau telaah dokumen untuk memperoleh data-data yang dibutuhkan dalam kajian ini. Penulis mengumpulkan data dan informasi dari berbagai sumber tertulis (baik konvensional maupun digital). Penulis juga telah mengumpulkan, membaca, dan menelaah data yang berbentuk tulisan dan gambar dari berbagai sumber tertulis (buku, artikel jurnal ilmiah, dan website) mengenai budaya, teknologi, dan televisi.

\section{HASIL DAN PEMBAHASAN}

Semenjak TVRI mengudara di Indonesia pada tahun 1962, televisi menjadi media komunikasi massa yang tidak bisa dilepaskan dari keseharian audiens di Indonesia. Menonton televisi melibatkan interaksi antara penonton dengan program televisi, serta berlangsung dalam ruang dan waktu dengan latar sosial budaya tertentu (Triwardani, 2012). Di awal kemunculannya, televisi masih merupakan barang mewah yang tidak dapat dikonsumsi sembarang orang. Oleh karena itu, tidak aneh jika pada awal kemunculannya, orang-orang Indonesia masih sering menonton televisi secara berkelompok/beramai-ramai, baik itu di rumah salah seorang warga yang memiliki 
televisi maupun di tempat-tempat umum seperti di balai desa atau kantor kecamatan.

Bahkan, dulu ada pajak yang khusus dikenakan bagi orang yang memiliki televisi di rumahnya. Pajak ini disebut "iuran televisi". Iuran tersebut diberlakukan berdasarkan Keputusan Presiden No. 40 Tahun 1990 tentang Pemungutan Iuran Penerima Pesawat Televisi (Mon, 2017). Melihat jauh ke belakang, sebetulnya pajak televisi baru dijalankan pada tahun 1963, berdasarkan Kepres RI Nomor 218. Pemilik pesawat televisi wajib menyumbang Rp. 300,00 per bulan. Sejak masuknya televisi berwarna ke Indonesia pada tahun 1970-an, besaran iuran televisi menjadi bervariasi. Besaran iuran Rp. 1.000,00 (hitam putih) dan Rp. 4.000,00 (berwarna) per bulan dikenakan untuk pesawat televisi yang berukuran di bawah 16 inchi. Khusus untuk pesawat televisi hitam putih berukuran di atas 16 inchi, diwajibkan membayar iuran Rp. 3.000,00 per bulan. Untuk pesawat televisi berwarna yang memiliki ukuran 16 sampai dengan 19 inchi, dikenakan biaya Rp. 5.000,00 per bulan dan yang berukuran lebih dari 19 inchi dikenakan biaya iuran sebesar Rp. 6.000,00 per bulan. Iuran bulanan amat diperlukan, karena motto TVRI adalah "Siaran Kami Ada Karena Iuran Televisi Anda". Untuk dapat mengudara, dahulu TVRI sangat mengandalkan hasil iuran masyarakat (Susantio, 2016).
"Iuran televisi” tersebut seakan menegaskan bahwa televisi adalah barang yang eksklusif; selain berharga cukup mahal pada saat itu, pemiliknya pun diharuskan membayar pajak televisi setiap bulannya. Tetapi, masih banyak warga yang tidak bersedia membayar iuran televisi. Seringkali aparat berwenang harus melakukan razia dalam rangka menagih iuran televisi. Segala cara dilakukan karena tidak bersedia membayar iuran. Alasan utama enggan membayar iuran, karena letak kantor pos cukup jauh. Di awal dekade 1990-an, Yayasan TVRI bekerja sama dengan pihak ketiga menggunakan metode jemput bola dengan mendatangi rumah warga yang memiliki pesawat televisi, dan metode ini cukup efektif, meskipun belum optimal. Agar lebih optimal, penyelenggara memberikan kupon undian berhadiah uang tunai untuk warga yang taat membayar. Besaran uangnya cukup fantastis saat zaman tersebut, smapai menyentuh kisaran jutaan rupiah (Susantio, 2016).

Semenjak pajak televisi ditiadakan di tahun 1996 akibat kemunculan 5 stasiun televisi swasta (RCTI, SCTV, TPI, Indosiar, dan ANTV) (Susantio, 2016), televisi terrestrial yang berformat analog (menggunakan antena) menjadi media hiburan utama bagi audiens di Indonesia. Fungsi televisi pun semakin luas, yang pada awalnya hanya sebagai media hiburan kemudian melebar memiliki fungsi 
informasi dan edukasi. Mulai dekade 70-an, televisi di Indonesia menjadi industri media massa karena industri barang dan jasa sudah mulai mempromosikan produknya melalui televisi, dan media audio visual ini pun dianggap media massa paling efektif dibanding media massa lainnya karena lebih atraktif; selain telah dimiliki oleh sebagian besar rumah tangga.

Dari fungsi informasi, televisi juga menjadi media yang lebih atraktif dan lebih aktual dibanding media cetak dalam menyiarkan informasi yang terjadi. Jika media cetak baru akan menyiarkan berita esok paginya, televisi bisa memberitakan sore atau malam harinya, bahkan siaran langsung di tempat kejadian sehingga aktualitas televisi lebih unggul dibanding media cetak. Hampir semua stasiun televisi memiliki acara siaran berita yang dikemas dengan sangat menarik. Kelemahan siaran televisi yang dinilai dengan sifatnya yang selintas dan tidak mendalam dalam menyiarkan informasi, saat ini sudah tidak berlaku lagi karena dalam acara siaran berita hampir setiap malam di televisi tertentu ada talkshow atau wawancara khusus yang secara mendalam menggali permasalahan hingga tuntas, bahkan perdebatan terbuka antara dua kubu yang berseberangan pun sekarang menjadi tontonan hiburan tersendiri (Abdullah \& Puspitasari, 2018).

Karena dianggap menguntungkan dari sisi bisnis, banyak pengusaha yang ikut turun ke bisnis televisi. Investasi ratusan milyar hingga trilyunan rupiah digelontorkan untuk industri televisi ini. Mereka memiliki keyakinan bahwa bisnis televisi bisa mengembalikan investasi yang ditanam dalam waktu yang relatif singkat. Para pengusaha media massa ini melihat kue iklan di Indonesia yang pada tahun 2016 saja mencapai angka sekitar Rp 150 trilyun. Dari jumlah itu sekitar $80 \%$ diraup oleh stasiun televisi besar di Jakarta yang jumlahnya hanya beberapa buah. Sedangkan stasiun TV lokal di daerah belum bisa menikmati gurihnya kue iklan ini karena berbagai keterbatasan (Abdullah, Rosfiantika, \& Permana, 2017).

Karena itulah, berbagai cara dilakukan agar khalayak menonton acara-acara yang ditampilkan televisi swasta. Dari pagi hingga pagi lagi, berupaya untuk dapat meraih minat khalayak untuk menonton. Semakin banyak penoton akan semakin banyak iklan yang akan diraih. Mereka berupaya menyuguhkan acara di waktu utama (prime time) dimana di waktu ini jumlah penonton yang paling banyak sehingga tarif iklannya pun yang termahal. Prime time televisi itu berkisar antara pukul 18.00 s.d. 22.00 (Abdullah et al., 2017).

Budaya menonton televisi terrestrial audiens di Indonesia sebelum adanya televisi digital fokus pada waktu prime time, di mana pada pukul 18.00 s.d. 22.00 merupakan 
waktu keluarga berkumpul. Biasanya, seluruh anggota keluarga berkumpul di depan televisi dalam sebuah ruangan dan menonton acara televisi bersama. Dahulu, televisi adalah benda yang terletak di ruang tertentu di dalam rumah. Kehadiran televisi membawa beberapa perbedaan dalam interaksi dan relasi antar anggota keluarga. Televisi yang berada dalam ruang keluarga menjadikan anggota keluarga sebagai pemirsa televisi dengan pola-pola berbeda dalam derajat keaktifan atau kepasifan, pilihan, minat, komitmen atau perhatian dalam aktivitas menonton yang dilakukan (Triwardani, 2012).

Sesi "nonton bareng" tersebut biasanya dijadikan juga sesi mengobrol antar anggota keluarga mengenai aktivitas apa saja yang telah dilakukan selama sehari penuh oleh masingmasing anggota keluarga. Hal itu berlaku bagi keluarga yang hanya memiliki satu pesawat televisi saja. Berbeda halnya jika ada satu keluarga yang memiliki lebih dari satu pesawat televisi, di mana anggota keluarga dapat menonton televisi di waktu yang berbeda dan di ruangan yang berbeda pula, atau bahkan menonton satu acara televisi di waktu yang sama, tetapi di ruangan berbeda. Terkait dengan peran media yang menjadi salah satu bagian yang tak terpisahkan dalam konteks hubungan dalam keluarga, David Croteau dan William Hoynes memiliki pandangan yang menarik, seperti yang tertuang dalam kutipan berikut ini:

"In more subtle ways, media are often part of our most routine relations with our families and close friends. Families often watch television together, huddled around the "electronic hearth". Timestrapped parents sometimes use the TV as a surrogate babysitter, allowing their children to watch hours of television at one sitting-often on a TV set in the children's bedroom," (Croteau \& Hoynes, 2014).

Budaya menonton televisi terrestrial secara berkelompok tersebut mulai tergeser semenjak kehadiran Internet di Indonesia pada awal abad millenium baru di tahun 2000-an. Internet merupakan sebuah jaringan komputer dunia yang mengembangkan ARPANET, suatu sistem komunikasi yang terkait dengan pertahanankeamanan yang dikembangkan pada tahun 1960-an (Severin \& Tankard, 2008). Internet seakan menghilangkan batas ruang dan waktu, di mana orang-orang di seluruh dunia dapat berinteraksi dengan cepat dan mudah. Fitur Internet yang paling populer adalah e-mail (fitur bertukar pesan melalui Internet) dan world wide web (www), sebuah sistem website komputer yang sangat luas dan dapat diakses oleh siapa saja dengan program browser serta dengan menyambungkan perangkat pada jaringan Internet.

Pilihan aktivitas yang makin beragam dengan waktu yang terbatas berdampak pada tuntutan kebutuhan manusia akan media yang 
bersifat mudah, mobile, dan aplikatif. Manusia memerlukan media multifungsi yang mampu menghilangkan berbagai batasan ruang dan waktu, yang dapat diakses kapanpun dan di manapun. Pada akhirnya, muncul konvergensi media sebagai teknologi media yang dapat menjawab kebutuhan tersebut (Gemiharto, 2015).

Indonesia memiliki jumlah pengguna Internet mencapai 63 juta jiwa, di mana 95\% angka pengguna Internet adalah pengguna media sosial dan $65 \%$ di antaranya merupakan pengguna media sosial Facebook, melansir data dari Kementrian Komunikasi dan Informatika (Kemenkominfo) (Soffani \& Nugroho, 2019). Dengan semakin mudahnya akses Internet di Indonesia, baik itu di kota-kota besar hingga ke sebagian wilayah urban dan pelosok Indonesia, televisi digital dengan Internet kabel pun bermunculan. Sekarang, perusahaan-perusahaan televisi kabel saling berlomba menggantikan kabel-kabel tembaga dengan kabel serat optik untuk mengirimkan lebih banyak data dan gambar yang lebih tajam. Serat optik dapat membawa sinyal-sinyal yang membuat gambar di televisi setajam gambar di layar komputer. Dalam kenyataannya, perusahaan televisi kabel memandang masa depan mereka berada di dalam kemampuan mereka untuk memberikan berbagai macam layanan telekomputer (Vivian, 2015).
Dengan mengaplikasikan konvergensi media dalam paket-paket yang ditawarkannya, perusahaan-perusahaan televisi kabel berlombalomba menawarkan produknya kepada audiens. Biasanya, paket yang mereka tawarkan adalah paket Internet, televisi berbayar, dan telepon.

Media Partners Asia menyatakan bahwa industri televisi berbayar di Asia Pasifik, khususnya di Indonesia, terus menunjukkan peningkatan. Berdasarkan data-data tersebut, dijelaskan bahwa penghasilan dari perusahaan televisi berbayar selama tahun 2017 meningkat sebanyak 5\% dibandingkan tahun sebelumnya ("10 Rekomendasi Layanan Televisi Kabel Terbaik dengan Harga Terjangkau yang Bisa Jadi Sumber Informasi dan Hiburan (2018),' 2018)

Beberapa perusahaan penyedia (provider) televisi kabel di Indonesia di antaranya adalah First Media, MNC Sky Vision, Orange TV, TransVision, MyRepublic, Nexmedia, Big TV, Biznet Home, Indovision, dan IndiHome. Perusahaan-perusahaan ini menawarkan paketpaket yang beragam, mulai dari pilihan paket dengan koneksi Internet dengan bandwith yang sedang hingga besar, sampai pada pilihan channel televisi (baik stasiun televisi dalam maupun luar negeri) yang banyak dan beragam. Konsumen dapat memilih provider manapun, asalkan layanannya tersedia di daerah/kota mereka dan sesuai dengan budget, karena biaya 
per bulan dari paket yang ditawarkan secara umum dari seluruh provider yang disebutkan di atas berkisar antara Rp. 250.000,00 s.d. Rp. $3.000 .000,00$.

Sebetulnya, satu hal yang menarik ialah jika satu keluarga di Indonesia berlangganan televisi kabel, hal tersebut seolah mengembalikan "iuran televisi" yang dulu pernah ada. Hanya saja, perbedaannya, jika dulu orang yang memiliki pesawat televisi diwajibkan membayar iuran berdasarkan jenis dan ukuran televisi yang dimiliki dengan biaya tertentu menggunakan dasar Keputusan Presiden RI dan dengan tujuan "menghidupkan" TVRI, sekarang orang berlangganan televisi kabel sesuai dengan kehendak mereka, dengan kata lain, besaran bandwith Internet dan pilihan channel sesuai dengan selera, kebutuhan, dan budget yang dimiliki.

Perkembangan teknologi Internet untuk menonton televisi juga turut memengaruhi budaya menonton televisi di Indonesia. Berkat kehadiran smartphone, menonton sebuah acara televisi pun sekarang dapat dilakukan melalui smartphone secara streaming kapan saja dan di mana saja. Hal ini tentu saja mengaburkan hasil riset lembaga pembuat rating yang kabarnya mengukurjumlah penonton sebuah acara melalui alat yang dipasang di rumah responden. Karena jumlah penontonnya berkurang, ratingnya juga ikut turun sehingga mempengaruhi pemasang iklan yang berpatokan kepada jumlah penonton sebuah acara (Abdullah \& Puspitasari, 2018).

Perkembangan teknologi Internet terkait dengan budaya dan kebiasaan menonton televisi ini juga menimbulkan pergeseran waktu dan pergeseran ruang dalam menonton televisi. Budaya telah berubah, karena budaya meliputi sebuah jaringan kerja dalam dalam kehidupan manusia dan melibatkan sekelompok orang, tidak hanya individu (Kusuma \& Nurhayati, 2017).

Pergeseran paradigma sedang terjadi. Dari aspek pergeseran waktu, orang tidak lagi menyesuaikan diri dengan jadwal acara televisi. Dahulu, orang menyesuaikan waktu menonton televisi dengan jadwal televisinya. Kini sebaliknya, orang akan menonton jika jadwal acara televisi sesuai dengan jadwal mereka. Ini bisa dikatakan sebagai "pemberdayaan audien" (Vivian, 2015).

Dari aspek pergeseran ruang, kini orang tidak lagi selalu menonton televisi di satu tempat saja, tetapi berkat adanya teknologi televisi portabel yang berukuran kecil atau menonton secara streaming melalui smartphone atau aplikasi program televisi (misalnya Vidio. com-nya EMTEK Group atau Zulu.id-nya NET.), orang bisa menonton televisi di mana saja, dengan syarat tersedia koneksi Internet. Audien on-the-move, dengan layar seukuran lelapak tangan, tidak duduk di satu tempat atau 
punya waktu luang yang cukup untuk menonton seluruh acara selama durasinya (Vivian, 2015).

Generasi Milenial atau Generasi Y dan Generasi $\mathrm{Z}$ yang telah akrab dengan teknologi dan smartphone, dan Internet sangat banyak menggunakan cara-cara menonton televisi seperti itu. Generasi Milenial adalah kelompok manusia yang lahir di atas tahun 1980-an hingga tahun 1997. Kelompok ini disebut milenial karena mereka adalah satu-satunya generasi yang pernah melewati milenium kedua sejak teori generasi ini diungkapkan pertama kali oleh Karl Mannheim pada tahun 1923 (Adam, 2017).

Sedangkan Generasi Z dikenal sebagai kelompok manusia yang berkarakter lebih tidak fokus dari milenial, namun lebih serba bisa, lebih individual, lebih global, berpikiran lebih terbuka, lebih cepat masuk ke dunia kerja, lebih berjiwa enterpreneur, dan tentu saja lebih ramah teknologi. Kedekatan generasi ini dengan teknologi sekaligus membuktikan masa depan sektor tersebut akan semakin cerah di tangan mereka. Dari segi ekonomi, menurut survei Nielsen, Generasi Z sudah memengaruhi perputaran ekonomi dunia sebagai $62 \%$ konsumen pembeli produk elektronik. Ini dipengaruhi oleh kehidupan mereka yang sudah serba terhubung dengan Internet (Adam, 2017).

\section{SIMPULAN}

Budaya menonton televisi di Indonesia berawal dari mengudaranya TVRI pada tahun 1962. Pada masa itu, televisi masih berwarna hitam-putih. Setelah hampir 30 tahun mengudara, kemunculan televisi-televisi swasta nasional di akhir tahun 1980-an menambah semarak pilihan audiens dalam menonton televisi yang pada saat itu telah berkembang menjadi televisi berwarna. Televisi pada rentang tahun 1960-1990-an yang pada waktu itu masih mengharuskan sang pemilik pesawat televisi membayar iuran per bulan masih merupakan barang mewah yang tidak bisa dibeli oleh sembarang orang. Alhasil, budaya menonton televisi terrestrial yang bersifat analog dan mengandalkan antena merupakan kegiatan komunal, di mana ketika menonton televisi, audiens lebih sering melakukannya secara berkelompok/bersama-sama,baik itu di tempattempat umum maupun di ruang keluarga. Kegiatan menonton televisi secara kolektif ini juga sekaligus merupakan kegiatan bertukar cerita keseharian audiens.

Namun semenjak kehadiran Internet, yang menimbulkan konvergensi media, termasuk televisi, budaya menonton televisi menjadi kegiatan yang lebih personal dan individual. Semenjak awal millenium baru, di mana teknologi Internet untuk menonton televisi 
juga semakin berkembang, audiens menjadi lebih memiliki "kuasa" dalam menentukan pilihan acara televisi yang ingin mereka tonton.

Era televisi digital yang mengandalkan jaringan Internet juga menimbulkan pergeseran ruang dan waktu dalam budaya menonton televisi, di mana smartphone yang bersifat portabel bisa digunakan untuk menonton acara televisi, kapan pun dan di mana pun. Generasi Y atau Generasi Milenial dan Generasi Z yang telah terbiasa terpapar dengan teknologi digital dan Internet menjadi generasi mayoritas penonton televisi digital.

\section{DAFTAR PUSTAKA}

10 Rekomendasi Layanan Televisi Kabel Terbaik dengan Harga Terjangkau yang Bisa Jadi Sumber Informasi dan Hiburan (2018). (2018). Retrieved March 8, 2019, from Best Present website: https://bpguide.id/AXQWryBR

Abdullah, A., \& Puspitasari, L. (2018). Media televisi di era internet. ProTVF: Jurnal Kajian Televisi Dan Film, 2(1), 101-110.

Abdullah, A., Rosfiantika, E., \& Permana, R. S. M. (2017). Siaran televisi pagi hari (breakfast television) di televisi Indonesia. ProTVF: Jurnal Kajian Televisi Dan Film, 1(2), 163-167.

Adam, A. (2017). Selamat Tinggal Generasi Milenial, Selamat Datang Generasi Z Tirto.ID. Retrieved March 8, 2019, from tirto.id website: https://tirto.id/selamattinggal-generasi-milenial-selamat-datanggenerasi-z-cnzX

Ardianto, E., Komala, L., \& Karlinah, S. (2007).
Komunikasi massa: suatu pengantar.

Bandung: Simbiosa Rekatama Media.

Bungin, B. (2011). Penelitian kualitatif: komunikasi, ekonomi, kebijakan publik, dan ilmu sosial lainnya (2nd ed.). Jakarta: Kencana Prenadamedia Group.

Candraningrum, D. A. (2017). Gangguan komunikasi publik dan penurunan brand engagement di perusahaan toys"r"us. Jurnal Komunikasi Global, 6(2), 164-174. Cangara, H. (2007). Pengantar ilmu komunikasi (edisi revisi). Jakarta: RajaGrafindo Persada.

Cholis, N., \& Wardiana, D. (2018). Manajemen strategi redaksi dan bisnis koran olahraga topskor dalam menghadapi persaingan dengan media online di era konvergensi media. Jurnal Kajian Jurnalisme, 1(2), 124-146.

Croteau, D., \& Hoynes, W. (2014). Media/ Society. Thousand Oaks: SAGE Publications.

Fachruddin, A. (2014). Dasar-dasar produksi televisi: produksi berita, feature, laporan investigasi, dokumenter, dan teknik editing. Jakarta: Kencana.

Gemiharto, I. (2015). Teknologi 4G-LTE dan Tantangan Konvergensi Media di Indonesia. Jurnal Kajian Komunikasi, 3(2), 212-220. https://doi.org/10.1037/h0048001

Holmes, D. (2012). Teori komunikasi: media, teknologi, dan masyarakat. Yogyakarta: Pustaka Pelajar.

Kusuma, P. K. N., \& Nurhayati, I. K. (2017). Analisis semiotika roland barthes pada ritual otonan di Bali. Jurnal Manajemen Komunikasi, 1(2), 195-217. https://doi. org/10.24198/jmk.v1i2.10519

Mon. (2017). Nostalgia, Anak Tahun 90-an Pasti Hapal Buku Iuran Televisi, Begini Penjelasannya - Tribun Jogja. Retrieved 
March 8, 2019, from TRIBUNJOGJA.

COM website: http://jogja.tribunnews. com/2017/07/14/nostalgia-anak-tahun-90an-pasti-hapal-buku-iuran-televisi-beginipenjelasannya

Pala, R. (2017). Televisi dan masyarakat perkotaan (survai kebiasaan menonton tv masyarakat Kelurahan Tammamaung Kecamatan Panakkukang Kota Makassar Provinsi Selawesi Selatan). Jurnal Studi Komunikasi Dan Media, 21(2), 193-201.

Permana, R. S. M., \& Mahameruaji, J. N. (2019). Model bisnis media net. tv dalam konteks persaingan stasiun televisi di era digital. in komunikasi, budaya, \& media dalam jaringan (pp. 173-195). Bandung: BITREAD Publishing.

Porter, R. E., \& Samovar, L. A. (2006). Suatu pendekatan terhadap komunikasi antar budaya. in $d$. mulyana \& $j$. rakhmat (eds.), komunikasi antarbudaya: panduan berkomunikasi dengan orang-orang berbeda budaya (pp. 11-35). Bandung:
Remaja Rosdakarya.

Rakhmat, J. (2012). Metode penelitian komunikasi: dilengkapi contoh analisis statistik. Bandung: Remaja Rosdakarya.

Samovar, L. A., Porter, R. E., \& McDaniel, E. R. (2014). Komunikasi lintas budaya (7th ed.). Jakarta: Salemba Humanika.

Severin, W. J., \& Tankard, J. W. (2008). Teori komunikasi: sejarah, metode, dan terapan di dalam media massa (5th ed.). Jakarta: Kencana.

Soffani, A., \& Nugroho, C. (2019). Unsur budaya dalam media sosial: studi pada facebook Kang Dedi Mulyadi. Jurnal Manajemen Komunikasi, 3(2), 158-172. https://doi.org/10.24198/jmk.v3i2.12936 Sugiyono. (2010). Metode penelitian kuantitatif, kualitatif, dan r\&d. Bandung: Alfabeta.

Susantio, D. (2016). Pajak Radio dan Pajak Televisi Hilang Ditelan Modernisasi oleh Djulianto Susantio - Kompasiana.com. Retrieved March 8, 2019, from Kompasiana website: https://www.kompasiana.com/ 